\title{
CD23 Antigen Regulation and Signaling in Chronic Lymphocytic Leukemia
}

\author{
S. Fournier, G. Delespesse, M. Rubio, G. Biron, and M. Sarfati
}

Notre-Dame Hospital, University of Montreal, Montreal, Quebec H2L 4M1, Canada

\begin{abstract}
B lymphocytes from patients with chronic lymphocytic leukemia (B-CLLs), strongly express the CD23 antigen, a surface marker with significant prognostic importance in this disease. Because we previously reported that IL -4 shows a poor capacity for CD23 expression on B-CLLs, we first examined the possible mechanisms underlying CD23 overexpression on BCLLs and found that mitogen-activated CLL T cells release soluble factors that are capable, in synergy with IL-4, of strongly inducing CD23. Using neutralizing Abs, we noticed that the T-cell-derived enhancing activity is entirely ascribed to the combined effects of IFN $\gamma$ (potent inhibitor of CD23 on normal B cells), TNF $\alpha$ (which has no effect on normal B cells), and IL-2 (which has a slight enhancing effect on both CLL and normal B cells). Furthermore, recombinant IFN $\gamma$ as well as IFN $\alpha$, TNF $\alpha$, and IL-2 (but not IL-3, IL-5, IL-6, IL-7, and lymphotoxin) significantly enhance CD23 protein and mRNA expression on B-CLLs, in the presence or absence of IL-4. Inasmuch as optimal CD23 expression absolutely requires the combination of IFN $\gamma$, IL-2, TNF $\alpha$ (the production of which is increased in CLL disease), and IL-4, it was relevant to show that IL-4 mRNA is indeed expressed in fresh T-CLL cells. We next examined the possible role of $C D 23$ in the regulation of $B-C L L$ proliferation. Signaling through $\mathrm{CD23}$ via ligation of the antigen by $F\left(a^{\prime}\right)_{2}$ anti-CD23 MAb but not Fab fragments inhibits the cytokine-induced B-CLL DNA synthesis. It is concluded that the CD23 gene is abnormally regulated in B-CLL disease and that cross-linking of CD23 molecule delivers a negative growth signal to the leukemic B cells. (J. Clin. Invest. 1992. 89:1312-1321.) Key words: interferon- $\alpha \bullet$ interferon- $\gamma \bullet$ interleukin 4-CD23 antigen regulation • tumor necrosis factor- $\alpha$
\end{abstract}

\section{Introduction}

The CD23 antigen, previously identified as the low-affinity receptor for IgE ( $\left.\mathrm{Fc}_{\mathrm{E}} \mathrm{RII}\right)$, is a $45-\mathrm{kD}$ glycoprotein mainly expressed on the surface of IgM-positive and IgD-positive B cells (1). This molecule may also be found on monocytes, $T$ cells, platelets, eosinophils, Langerhans cells, and follicular dendritic cells (2). Membrane-bound CD23 is cleaved into soluble fragments, also known as IgE-binding factors (sCD23/IgE-

Some data in this article were presented to the American Society of Hematology and have appeared in abstract form (1990. Blood. 76:206a).

Received for publication 25 June 1991 and in revised form 28 October 1991.

J. Clin. Invest.

(c) The American Society for Clinical Investigation, Inc. $0021-9738 / 92 / 04 / 1312 / 10 \quad \$ 2.00$

Volume 89, April 1992, 1312-1321
BF), ${ }^{1}$ in that they are still capable of binding to IgE (3). IL-4 is the strongest inducer of CD23 expression (and sCD23/IgE-BF release) on most cell types including normal $B$ cells and monocytes $(2,4)$. CD23 may also be up-regulated by IL-2 on activated normal B cells as well as on leukemic B lymphocytes from patients with chronic lymphocytic leukemia (CLL); however, the effect of IL-2 is much less pronounced than that of IL-4 (5). Depending upon the cell type on which it is expressed, $\mathrm{CD} 23$ may be up- or down-regulated by IFN $\gamma$. IFN $\gamma$ is a potent inhibitor of CD23 expression on IL-4-stimulated normal B cells (6), Burkitt's lymphoma cell lines (7), and allergen-stimulated $\mathrm{T}$ cells of allergic patients (8). In contrast, IFN $\gamma$ up-regulates CD23 on Langerhans cells (9), platelets (10), the eosinophil EOL3 cell line, and the U937 monocytic cell line $(11,12)$. On normal monocytes, IFN $\gamma$ induces the release of sCD23/ IgE-BF, whereas its effect on surface CD23 expression is still a controversial issue (13-15). Finally, IFN $\gamma$ does not affect the constitutive CD23 expression on human T lymphocytic leukemia virus 1-transformed or on the majority of EBV-transformed cells (12). In contrast to IFN $\gamma$, IFN $\alpha$ inhibits IL-4-induced CD23 on normal B cells and on monocytes (13). Finally, agents such as corticosteroids, lipid mediators, and prostaglandin E2 also modulate CD23 expression (16-19).

Several biological activities have been ascribed to CD23 and its soluble fragments including the regulation of normal $B$ and $T$ cell proliferation (20-22) and the control of human IgE synthesis $(23,24)$. More recently, soluble CD23 and IL-1 were shown to have a synergistic effect on the maturation of prothymocytes (25), the proliferation of myeloid precursors (26), and the rescue of germinal center B cells from apoptosis (27).

We previously reported that CLL patients have increased levels of serum sCD23 (or IgE-BFs) (28) and that fresh, purified $B$ cells isolated from CLL patients (B-CLLs) express more CD23 than normal B cells (29). Moreover, we recently showed that IL-4 has a poor capacity for CD23 induction on B-CLLs, as opposed to its effect on normal B cells (30). In the present study, we first analyzed the mechanisms underlying CD23 overexpression on B-CLLs and next examined the influence of CD23 signaling on the growth of the leukemic B cells.

\section{Methods}

Reagents. Human recombinant IL-2 was purchased from Genzyme Corp. (Boston, MA). Recombinant IFN $\gamma$ and natural human IFN $\gamma$ were purchased from Alpha-Therapeutic Corp. (Los Angeles, CA) and Cellular Products (Buffalo, NY), respectively. Human recombinant IL-

1. Abbreviations used in this paper: CLL, chronic lymphocytic leukemia; B-CLLs and T-CLLs, purified B or T cells, respectively, isolated from CLL patients; GM-CSF, granulocyte/macrophage colony-stimulating factor; MFI, mean fluorescence intensity; PCR, polymerase chain reaction; $\mathrm{PDGF}$, platelet-derived growth factor, $\mathrm{sCD} 23 / \mathrm{IgE}-\mathrm{BF}$, IgE-binding factor or soluble CD23; TGF $\beta 2$, transforming growth factor- $\beta 2$; TNF $\alpha$, tumor necrosis factor- $\alpha$; T-PHA SUP, T cell supernatant derived from PHA-stimulated T-CLLs. 
4 was obtained from either Genzyme Corp. or from Dr. H. Hofstetter (CIBA-Geigy, Basel, Switzerland). IL-7 was obtained from Dr. S. Gillis (Immunex Corp., Seattle, WA). Recombinant IFN $\alpha$ was obtained from Schering Corp. (Kenilworth, NJ). Neutralizing anti-IL-4 MAb was a gift of Dr. C. Heusser (CIBA-Geigy). Transforming growth factor- $\beta 2$ (TGF $\beta 2$ ) was a gift of Dr. D. Cox (CIBA-Geigy). IL- $1 \alpha$ and $\beta$, IL-3, granulocyte/macrophage colony-stimulating factor (GM-CSF), $\mathrm{CSF}$, platelet-derived growth factor (PDGF) neutralizing anti-IFN $\gamma$, and anti-IL-2 MAbs were purchased from Genzyme Corp. Neutralizing anti-tumor necrosis factor- $\alpha$ (TNF $\alpha) \mathrm{Ab}$, recombinant TNF $\alpha$, lymphotoxin, and recombinant IL-5 were kindly given by Dr. W. Fiers (State University, Ghent, Belgium). Phytohemagglutinin (PHA) was purchased from Wellcome Diagnostics (Beckenham, UK).

Cell preparation and culture conditions. PBMC were isolated from peripheral blood of untreated CLL patients by density gradient centrifugation of heparinized blood as previously described (29). B and T cellenriched fractions were obtained by rosetting two times with 2-aminoethylisothiouronium bromide-sheep red blood cells (SRBC) and centrifugation on Ficoll-metrizoate. Monocyte depletion was accomplished by Sepracell density gradient (Sepratech Corp., Oklahoma City, $\mathrm{OK})$. For CD23 expression, highly purified B cells, containing no detectable $\mathrm{MO}^{+}$cells or $\mathrm{CD}^{+}$cells, as determined by FACS analysis, were cultured at $1.5 \times 10^{6} / \mathrm{ml}$ for $2 \mathrm{~d}$ in 48 -well tissue plates (Costar, Cambridge, MA) at $37^{\circ} \mathrm{C}$ in complete $\mathrm{HB} 101$ medium (Hanna Biologics, Berkeley, CA) supplemented with $5 \%$ FCS, 2 mM glutamine, 1 $\mathrm{mM}$ sodium pyruvate, $10 \mathrm{mM}$ Hepes, $100 \mathrm{IU}$ penicillin, and $100 \mu \mathrm{g} / \mathrm{ml}$ streptomycin. For B-CLL proliferation assays, B-CLLs were cultured for 2-5 $\mathrm{d}$ in 96 -well round-bottom plates $\left(4 \times 10^{5}\right.$ per well) in $\mathrm{HB} 101$ serum-free medium. Selected cultures were supplemented with TNF $\alpha$ $(25 \mathrm{ng} / \mathrm{ml})$, IFN $\alpha(500 \mathrm{U} / \mathrm{ml})$, IL-2 $(20 \mathrm{U} / \mathrm{ml})$ in the absence or presence of $\mathrm{F}\left(\mathrm{ab}^{\prime}\right)_{2}$ anti-CD23 MAb (clone 135) or its Fab fragments (21). Cross-linking of CD23 was done by mixing Fab fragments of CD23 MAb $(10 \mu \mathrm{g} / \mathrm{ml})$ with goat anti-mouse IgG (Fab specific) $(10 \mu \mathrm{g} / \mathrm{ml})$ (Sigma Chemical Co., St. Louis). Cells were pulsed with $0.5 \mu \mathrm{Ci}\left[{ }^{3} \mathrm{H}\right]-$ thymidine (Amersham Corp., Arlington Heights, IL) during the last 16 $h$ of the culture period and $\left[{ }^{3} \mathrm{H}\right]$ thymidine incorporation was measured by a standard liquid scintillation counter. Cultures were performed in quadruplicate and the results are expressed as the mean \pm 1 SD.

Preparation of $T$ cell supernatants derived from PHA-stimulated $T$-CLLs and fractionation by gel filtration on HPLC. 2-Amino-ethylisothiouronium bromide rosette-forming cells were treated with a buffered $\mathrm{NH}_{4} \mathrm{Cl}$ solution and washed extensively with Hanks' buffer. The $\mathrm{T}$ CLL cell-enriched $\left(>95 \% \mathrm{CD}^{+}\right.$cells) fraction $\left(3 \times 10^{6}\right.$ cells $\left./ \mathrm{ml}\right)$ was stimulated with $0.1 \%$ PHA in complete $\mathrm{HB} 101$ medium. After $3 \mathrm{~d}$, cells were harvested and the supernatant, referred to as T-PHA SUP, was

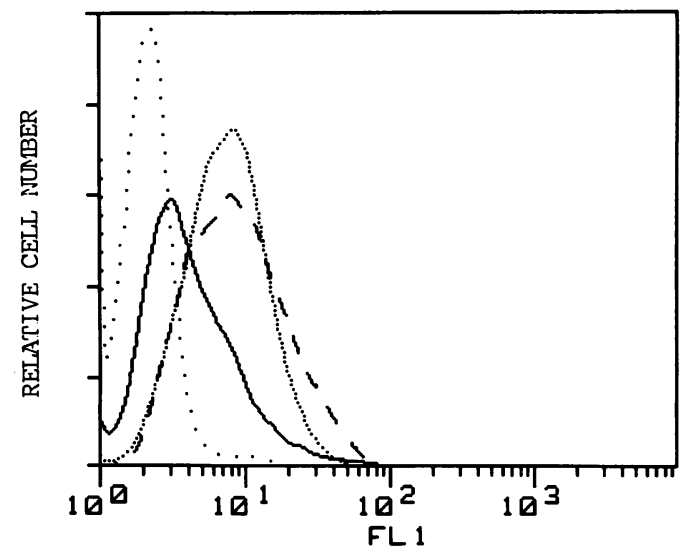

Figure 1. T-PHA SUP restores CD23 overexpression observed on fresh B-CLLs. CD23 expression on freshly isolated B-CLLs (…) and on B-CLLs cultured for $2 \mathrm{~d}$ with IL-4 $(10 \mathrm{ng} / \mathrm{ml})(-)$ or IL-4 plus T-PHA SUP (10\%) (- -). Control MAb is shown as (. . .). One representative experiment out of six. collected, dialyzed, and stored in aliquots at $-80^{\circ} \mathrm{C} .25 \mu$ of concentrated T-PHA SUP (15 times) were applied on a Biosil TSK 250 column (Bio-Rad Laboratories, Richmond, CA) and eluted with a buffer containing $0.05 \mathrm{M} \mathrm{Na}_{2} \mathrm{SO}_{4}$ and $0.02 \mathrm{M} \mathrm{NaH}_{2} \mathrm{PO}_{4}, \mathrm{pH} \mathrm{6.8}$, at a flow rate of $0.5 \mathrm{ml} / \mathrm{min}$. Each fraction $(0.25 \mathrm{ml})$ was tested at $20 \%$ (final concentration) for its ability to alter CD23 expression by IL-4-stimulated BCLLs (10 ng/ml). The column was calibrated by using the Bio-Rad gel filtration standards.

CD23 cell surface expression. $50 \mu \mathrm{l}$ of cultured cells $\left(10^{6} / \mathrm{ml}\right.$ in PBS-BSA) were incubated with $50 \mu$ l of biotinylated anti-CD23 MAb $(3 \mu \mathrm{g} / \mathrm{ml}$; clone 135$)$ or unrelated biotinylated control MAb of the same IgG sublcass specificity (anti-LoL p1) together with $50 \mu$ l of normal human IgG $(300 \mu \mathrm{g} / \mathrm{ml})$. After $2 \mathrm{~h}$ of incubation at $4^{\circ} \mathrm{C}$, followed by three washes with PBS-BSA, the cells were resuspended in $25 \mu \mathrm{l}$ of fluorescein isothiocyanate (FITC)-conjugated avidin (Becton, Dickinson, \& Co., Mountain View, CA). Of note, overnight incubation at $4^{\circ} \mathrm{C}$ was used to detect CD23 expression on fresh cells. After $30 \mathrm{~min}$ of incubation at $4^{\circ} \mathrm{C}$, followed by one wash with PBS-BSA and two washes with PBS, the cells were resuspended in PBS and analyzed using
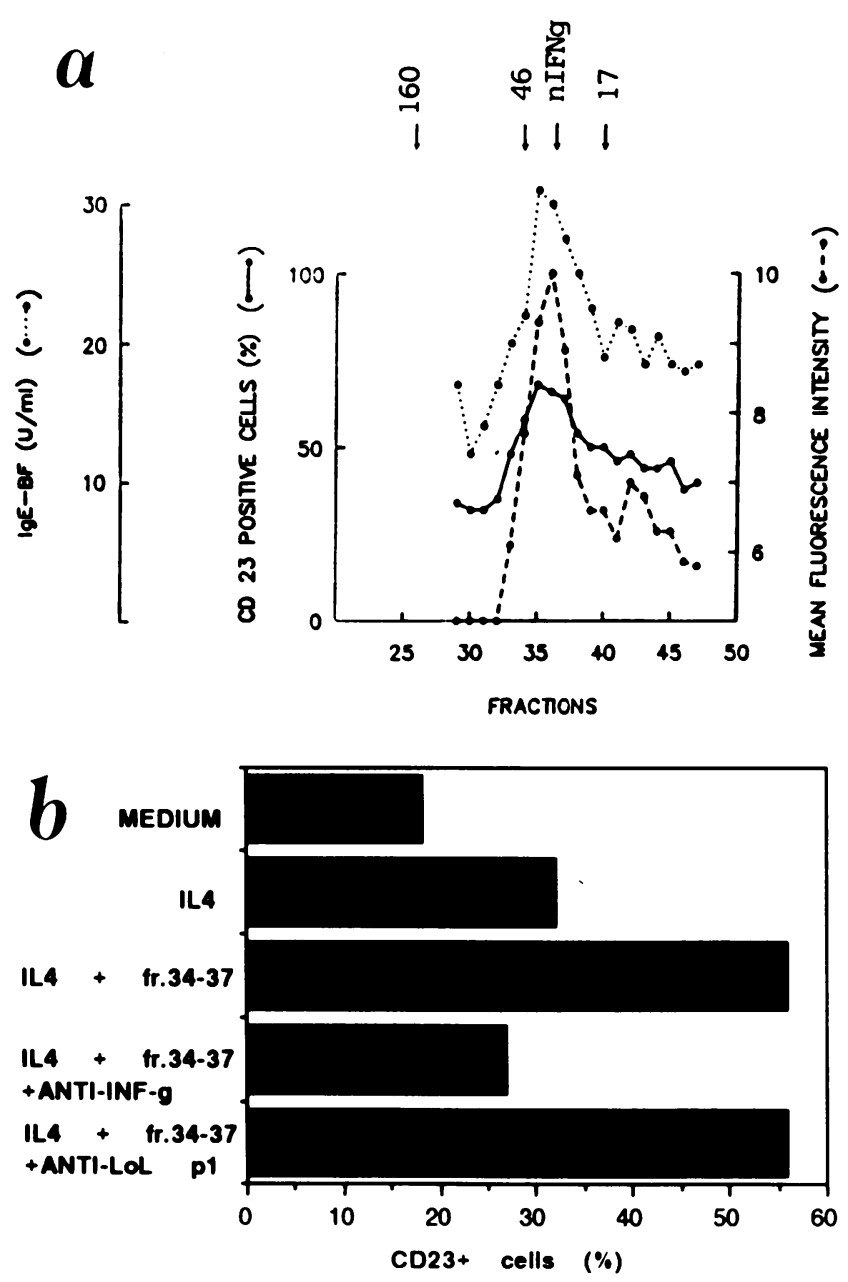

Figure 2. Fractionation by gel filtration of a T-PHA SUP. (a) B-CLLs were cultured for $2 \mathrm{~d}$ with IL-4 $(10 \mathrm{ng} / \mathrm{ml})$ and gel filtration fractions of a T-PHA SUP ( $20 \%$ final concentration). B-CLLs were assayed for $\mathrm{CD} 23$ expression and IgE-BF/sCD23 production as described in Methods. The major peak of elution of native human IFN $\gamma$ and $M_{\mathrm{r}}$ markers (in kilodaltons) are indicated by arrows. (b) B-CLLs were cultured in medium, IL-4 $(10 \mathrm{ng} / \mathrm{ml})$ or IL- 4 and the pool of fractions (fr.) 34-37 (20\%) of the gel filtration shown above. Anti-IFN $\gamma(200$ $\mathrm{U} / \mathrm{ml}$ ) or an unrelated MAb (anti-LoL pl) were added in selected cultures. After $2 \mathrm{~d}$, cells were stained for CD23 expression. 
a FACSCAN flow cytometer (Becton Dickinson \& Co.). Data were acquired in list mode by gating on the lymphocyte population. Final histogram analysis was performed using the CONSORT 30 software program (Becton, Dickinson \& Co.).

RIAs. sCD23/IgE-BF were measured by solid-phase RIA exactly as previously described (31). IFN $\gamma$ and TNF $\alpha$ were detected by a commercially available solid-phase RIA kit (Centocor Co., Malvern, PA), IL-2 was measured by an IL-2 RIA kit (AMI Research Products, Cambridge, MA) and IL-4 by an IL-4-ELISA kit (Genzyme Corp.).

PCR technique. Total RNA was isolated from normal T cells, $\mathrm{T}$ CLLs, or B-CLLs using the guanidium thiocyanate/cesium chloride method (32). $1 \mu \mathrm{g}$ of total RNA was reverse transcribed into cDNA using oligo-dT primer as described in the RNA polymerase chain reaction (PCR) kit from Perkin Elmer (Cetus Corp., Emeryville, CA). One half of the reverse-transcribed RNA mix was amplified with the $5^{\prime}$ and $3^{\prime}$ IL-4 primers which flanked 462 bases of the mature IL-4 message (33). The other half was amplified with the $5^{\prime}$ and $3^{\prime} \beta$-actin primers (33). The amplification procedure involved denaturation at $94^{\circ} \mathrm{C}$ for 1 min, annealing at $55^{\circ} \mathrm{C}$ for $2 \mathrm{~min}$, and extension at $72^{\circ} \mathrm{C}$ for $3 \mathrm{~min}$ during 35 PCR cycles. $10 \mu$ l of the $100 \mu$ l of PCR mix was separated on an $1.5 \%$ agarose gel and stained with ethidium bromide.

Northern blot analysis. Selected B-CLLs clones were incubated with IL-4 $(10 \mathrm{ng} / \mathrm{ml})$ or either IFN $\gamma(500 \mathrm{U} / \mathrm{ml})$, IFN $\alpha(500 \mathrm{U} / \mathrm{ml})$, or TNF $\alpha$ $(25 \mathrm{ng} / \mathrm{ml})$ in the presence or the absence of IL- 4 . When used, actinomycin D was added at $10 \mu \mathrm{g} / \mathrm{ml}$. Total RNA was isolated by the guanidium thyocyanate/cesium chloride procedure (32) and quantitated by absorbance at $260 \mathrm{~nm}$. A total of $10 \mu \mathrm{g}$ RNA was electrophoresed on $1 \%$ agarose gels containing formaldehyde and $1 \times 2-(N$-morpholino $)$ propane sulfonic acid. Gels were blotted onto a nylon membrane (ICN, Irvine, CA) and blots were hybridized overnight with a $1.25-\mathrm{kb} \alpha{ }^{32} \mathrm{P}-$ labeled nick-translated $\mathrm{CD} 23-\mathrm{cDNA}$ probe ( $\mathrm{PcL}_{2}$ probe). Membranes were then washed for two 15 -min periods at $25^{\circ} \mathrm{C}$ in $0.1 \% \mathrm{SDS} / 2$ $\times \mathrm{SSC}$ and for two 30 -min periods at $65^{\circ} \mathrm{C}$ in $0.1 \% \mathrm{SDS} / 0.2 \times \mathrm{SSC}$. Membranes were exposed to Kodak XAR film (Eastman Kodak Co., Rochester, NY) at $-70^{\circ} \mathrm{C}$ with enhancer screens. Equal loading of gels was assessed by methylene blue staining of the 28S and 18S RNAs (34).

\section{Results}

IFN $\gamma$ strongly increases the expression of CD23 by IL-4-stimulated $B$-CLLs. We previously reported that the overexpression of CD23 on fresh B-CLLs is associated with a poor capacity of IL-4 to up-regulate CD23 (29). Because we observed that costimulation of CLL PBMC with IL-4 and PHA leads to strong CD23 expression (30), we examined whether PHA-activated T cells may be replaced by their culture supernatants. As illustrated in Fig. 1, co-stimulation with T-PHA SUP and optimal concentration of IL-4 restores CD23 expression to the same level as on freshly isolated B-CLL cells. T-PHA SUP markedly enhances in a dose-dependent manner the IL-4-induced expression of CD23 and release of SCD23/IgE-BF (ranging from 50 to $115 \mathrm{U} / \mathrm{ml}$ ), indicating that the accumulation of cell surface CD23 is not due to inhibition of its cleavage. Five such T-PHA SUPs were tested on B-CLLs from five different patients with very consistent results (data not detailed). These data strongly suggested that molecules other than IL-4 are capable of up-regulating CD23 on B-CLLs.

Fractionation of T-PHA SUP on a Biosil TSK 250 gel filtration column reveals a peak of activity located exactly at the same position as native IFN $\gamma$ (nIFN $\gamma$ ) (Fig. 2 a). This prompted us to examine the effect of neutralizing MAb to IFN $\gamma$ on the activity of this peak. As seen in Fig. $2 b$, the activity is mediated by IFN $\gamma$ in that the neutralizing antibody completely blocks the CD23-inducing activity of this fraction. This unexpected observation was next confirmed by showing that, in five out of five CLL patients, recombinant IFN $\gamma$ significantly increases the expression of CD23 by IL-4-stimulated B-CLLs (Student's $t$ test [ $n=11] P<0.001$ ) (Table I). Moreover, in two patients, IFN $\gamma$ alone is capable of slightly up-regulating CD23. The potentiating activity of IFN $\gamma$ on IL-4-in-

Table I. Recombinant IFN Enhances IL-4-induced CD23 expression on B-CLLs

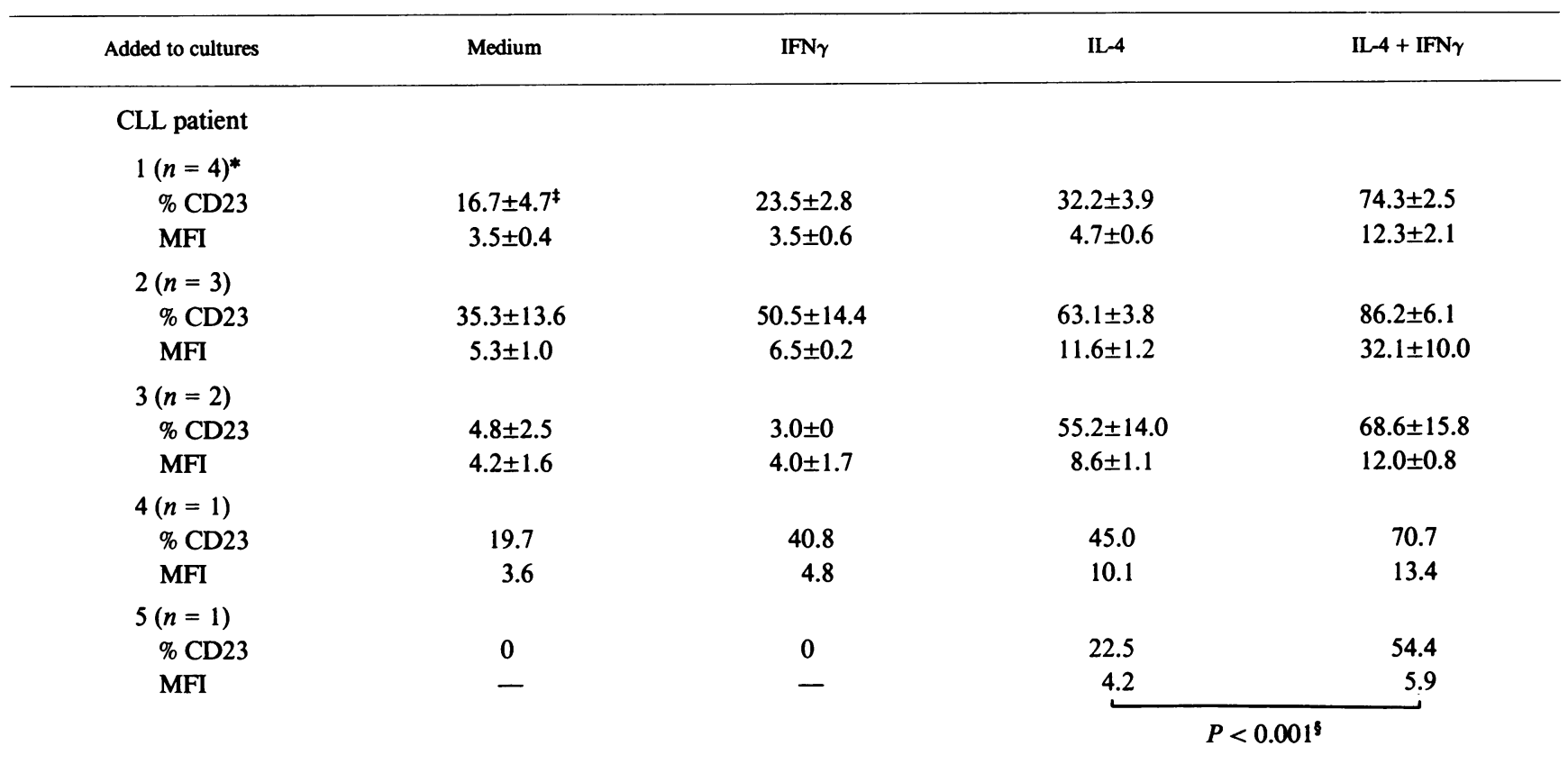

\footnotetext{
${ }^{*} n$ represents the number of experiments performed on each patient. ${ }^{\ddagger}$ Mean \pm 1 SD of $n$ experiments performed on the same patient. ${ }^{8} \mathrm{IFN} \gamma$
} $(500 \mathrm{U} / \mathrm{ml})$ significantly enhanced CD23 expression induced by IL-4 $(10 \mathrm{ng} / \mathrm{ml})(\%$ CD23 [n $=11]: P<0.001$, paired Student's $t$ test). 

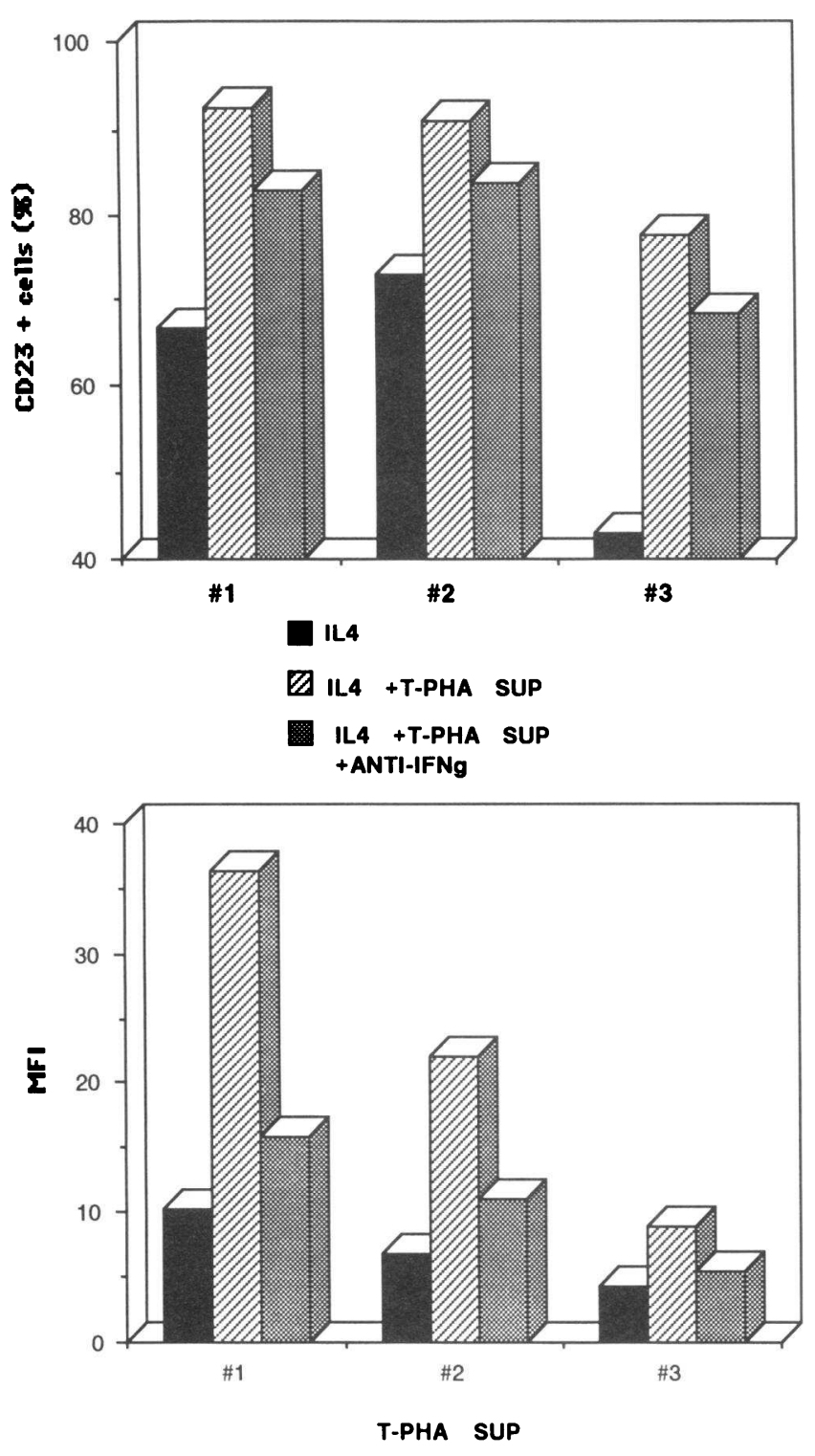

Figure 3. Effect of anti-IFN $\gamma$ MAb on the up-regulation of the IL-4mediated CD23 expression by unfractionated T-PHA SUPs. B-CLLs from one CLL patient were cultured with IL-4 $(10 \mathrm{ng} / \mathrm{ml})$ and three different T-PHA SUPs in the presence or absence of anti-IFN $\gamma$ MAb ( $200 \mathrm{U} / \mathrm{ml})$. After $2 \mathrm{~d}$, cells were stained for CD23 surface expression as described in Methods $\left(A\right.$, percentage of $\mathrm{CD} 23^{+}$cells; $B$, mean fluorescence intensity $[M F I])$.

duced CD23 expression is dose dependent (effective at $10 \mathrm{U} /$ $\mathrm{ml}$ ) and can be neutralized by anti-IFN $\gamma$ MAb (not shown).

$I F N \gamma$ does not account for the whole enhancing activity of $T-P H A$ SUP. We next showed that the neutralization of IFN $\gamma$ by large excess of anti-IFN $\gamma$ MAb (as evidenced by the measurement of IFN $\gamma$ in each supernatant by means of RIA) does not completely abolish the enhancing activity of unfractionated T-PHA-SUPs (30-40\% suppression), suggesting that other soluble factors are involved (Fig. 3). This was explored by examining a large panel of recombinant cytokines for their effect on CD23 expression and on the release of sCD23/IgE-BF by highly purified B-CLLs. As shown in Fig. 4, IFN $\gamma$, TNF $\alpha$, IFN $\alpha$, and IL-2 enhance IL-4-induced CD23. The following cytokines have no activity: IL-1, IL-3, IL-5, IL-6, IL-7, GM-
CSF, CSF, TGF $\beta$, PDGF, and lymphotoxin. The cytokine-enhancing effect is dose dependent and already significant at 5 $\mathrm{U} / \mathrm{ml}$ of IFN $\alpha$ and $1 \mathrm{ng} / \mathrm{ml}$ of TNF $\alpha$ (not shown). Of interest, all four cytokines upregulated IL-4-induced CD23 simultaneously in three out of five CLL patients, whereas the two other patients responded to IFN $\gamma$ and either IL-2 or TNF $\alpha$. The combination of IL-4 plus IFN $\gamma$ (not IFN $\alpha$ ), IL-2, and TNF $\alpha$ is required for optimal CD23 expression by B-CLLs. These experiments also indicated that IFNs and TNF $\alpha$ may induce CD23 expression in the absence of IL-4 on selected B-CLL clones (three of five patients). Finally, the CD23 up-regulation by IFNs and TNF $\alpha$ is always accompanied by an increase in CD23 mRNA (Fig. 5), that can be blocked by actimonycin D treatment.

The superinducing activity of T-PHA SUP is accounted for by the combined effects of $I L-2, I F N \gamma$, and $T N F \alpha$. Two approaches were used to determine whether the enhancing activity of T-PHA SUP may be ascribed to its content in IFN $\gamma$, IL-2, and TNF $\alpha$. We first observed that a cocktail of neutralizing MAbs directed against these lymphokines completely inhibits the CD23 superinducing activity of three T-PHA SUPs (Fig. 6 $B$ ). Having measured the concentration of IFN $\gamma, \mathrm{TNF} \alpha$, and IL-2 in supernatants by RIA, we next prepared cocktails made of recombinant lymphokines at the same concentrations as in the T-PHA SUP. The data in Fig. $6 C$, clearly show that two superimposed CD23 histograms are obtained using either TPHA SUP or the matched mixture of recombinant lymphokines.

$T C L L$ express $I L-4 m R N A$. Published reports indicated that selected B-CLL clones express TNF $\alpha$ mRNA (35) and are surrounded by a large number of activated $\mathrm{CD} 8^{+}$cells, known to be IFN $\gamma$ producers $(36,37)$. Because the in vitro reconstitution of CD23 overexpression on B-CLLs requires exposure to IFN $\gamma$, TNF $\alpha$, IL-2 plus IL-4, we examined whether IL-4 mRNA could be detected in T CLL cells, which are composed of a very low number of $\mathrm{CD} 4^{+}$cells (ratio $\mathrm{CD} 4^{+} / \mathrm{CD} 8^{+} \mathrm{T}-\mathrm{CLL}$ is $0.46 \pm 0.22$ ). As shown by PCR analysis (Fig. 7), all fresh T-CLLs samples tested (eight of eight) express IL-4 mRNA, suggesting that IL-4 can be produced in vivo in this disease. The gene is silent in B-CLLs (not shown) ruling out an autocrine expression of IL-4. Of note, fresh normal T cells (three out of four) also express IL-4 mRNA, as detected by PCR, whereas the IL- 4 message cannot be visualized by Northern blot analysis in $\mathrm{T}$ cells from either normal or leukemic donors (not shown).

Cross-linking of CD23 inhibits B-CLL DNA synthesis. Since it has been reported by several authors that CD23 is involved in the regulation of $B$ or $T$ cell proliferation, we tested whether signaling through CD23 could influence the growth of the B-CLL cells. We found that one anti-CD23 MAb (clone 135) strongly suppresses the cytokine-induced B-CLL DNA synthesis (Table II). The effect is dose dependent and not influenced by the presence of FCS in the medium (not shown). Importantly, anti-CD23 MAb inhibits rather than shifts the peak of cytokine-induced DNA synthesis. When used alone, the same MAb has no stimulatory effect or even suppresses spontaneous $\left[{ }^{3} \mathrm{H}\right]$ thymidine incorporation occurring at day 4 (Table II). Finally, Fig. 8 shows that cross-linking of CD23 by $\mathrm{F}\left(\mathrm{ab}^{\prime}\right)_{2}$ anti-CD23 or by monovalent Fab used in combination with goat anti-mouse Fab is required to inhibit B-CLLs growth. Hence, monovalent Fab fragments alone have no effect, strongly suggesting that membrane-bound CD23 rather 

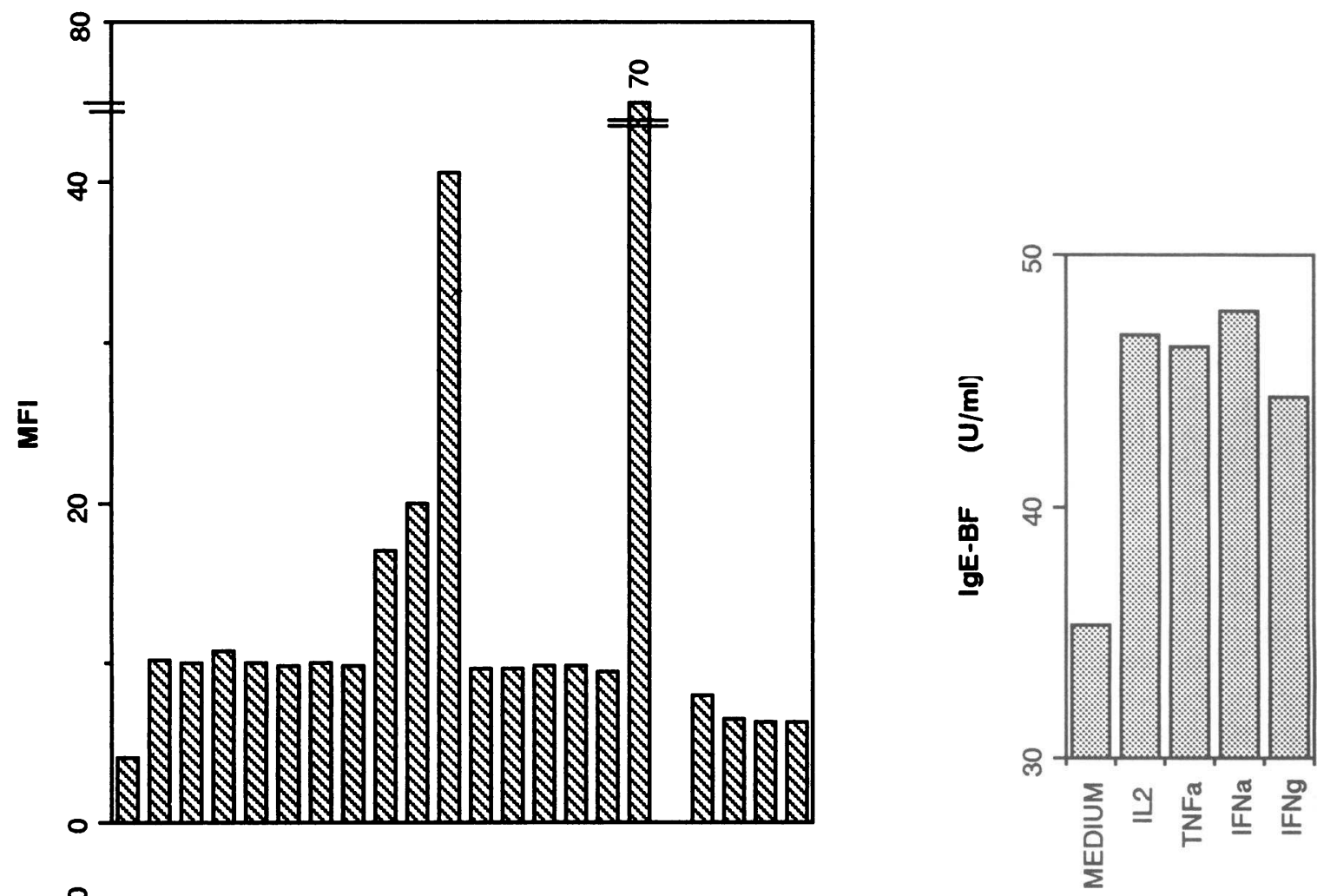

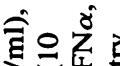

品

그을

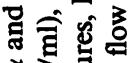

골를

킁

焉造

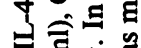

해힐

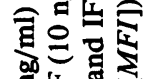

包岂

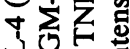

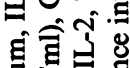

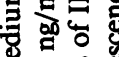

氠

帘氖

Z

莺领

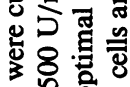

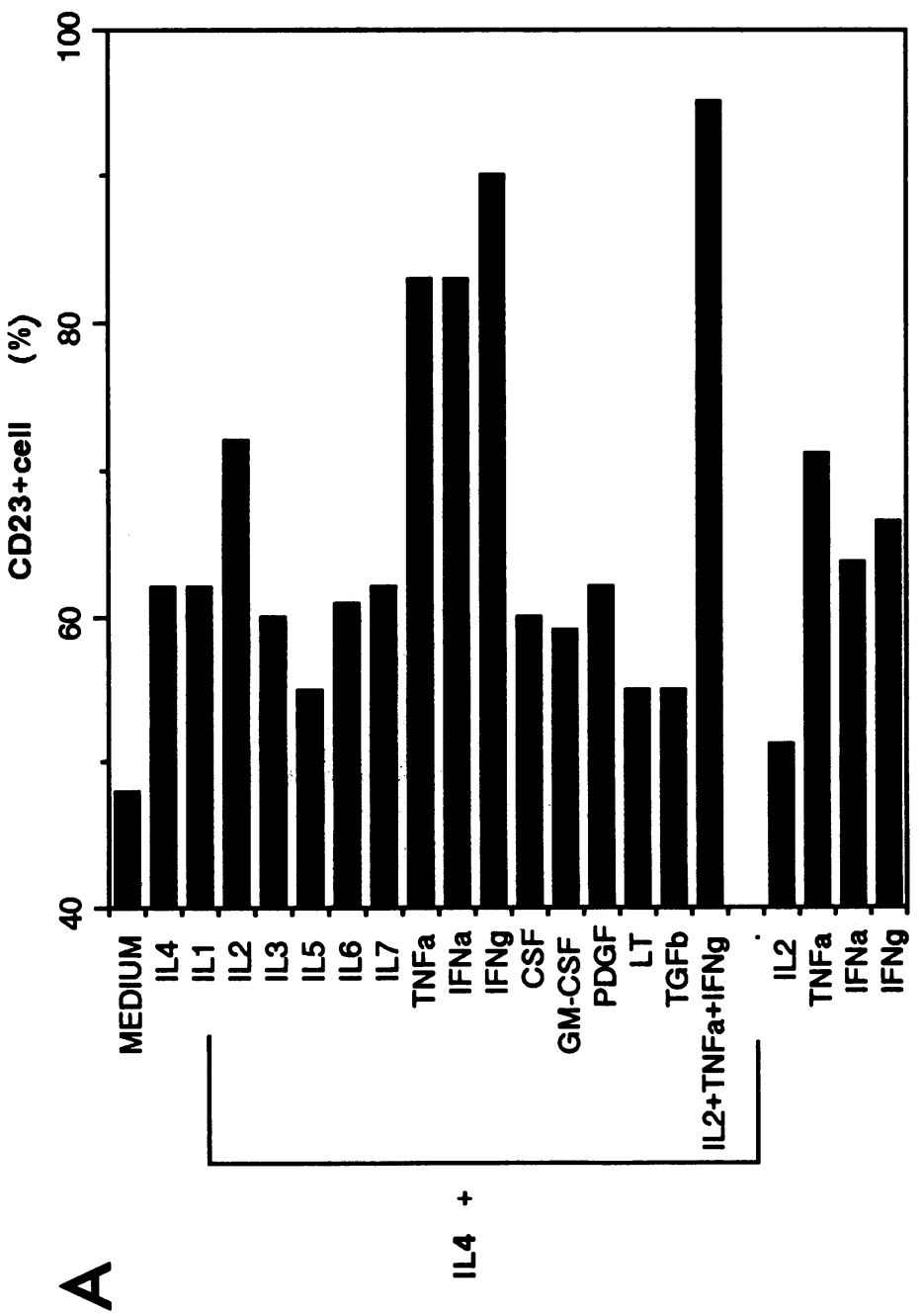

충

记它合

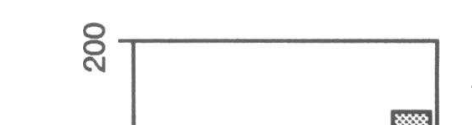

मे $\hat{\bar{\varepsilon}}$.

총

\&

遇

क国兵

\& $\hat{\overline{\mathrm{\varepsilon}}}$

항

율

年

了手这

ปิำ

由 3 过

它讨

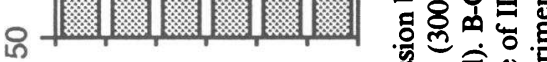

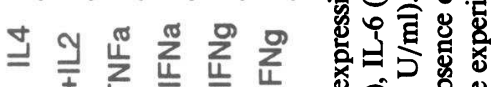

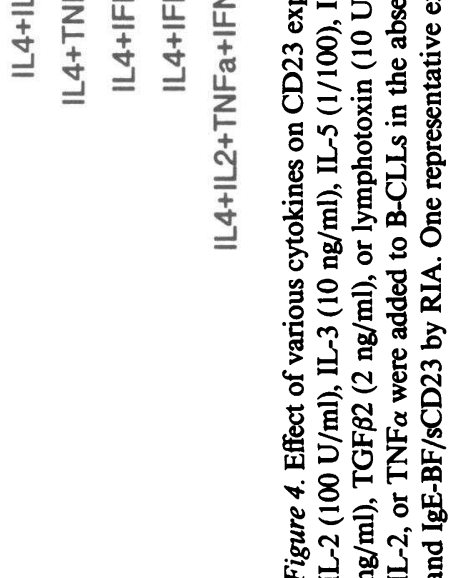




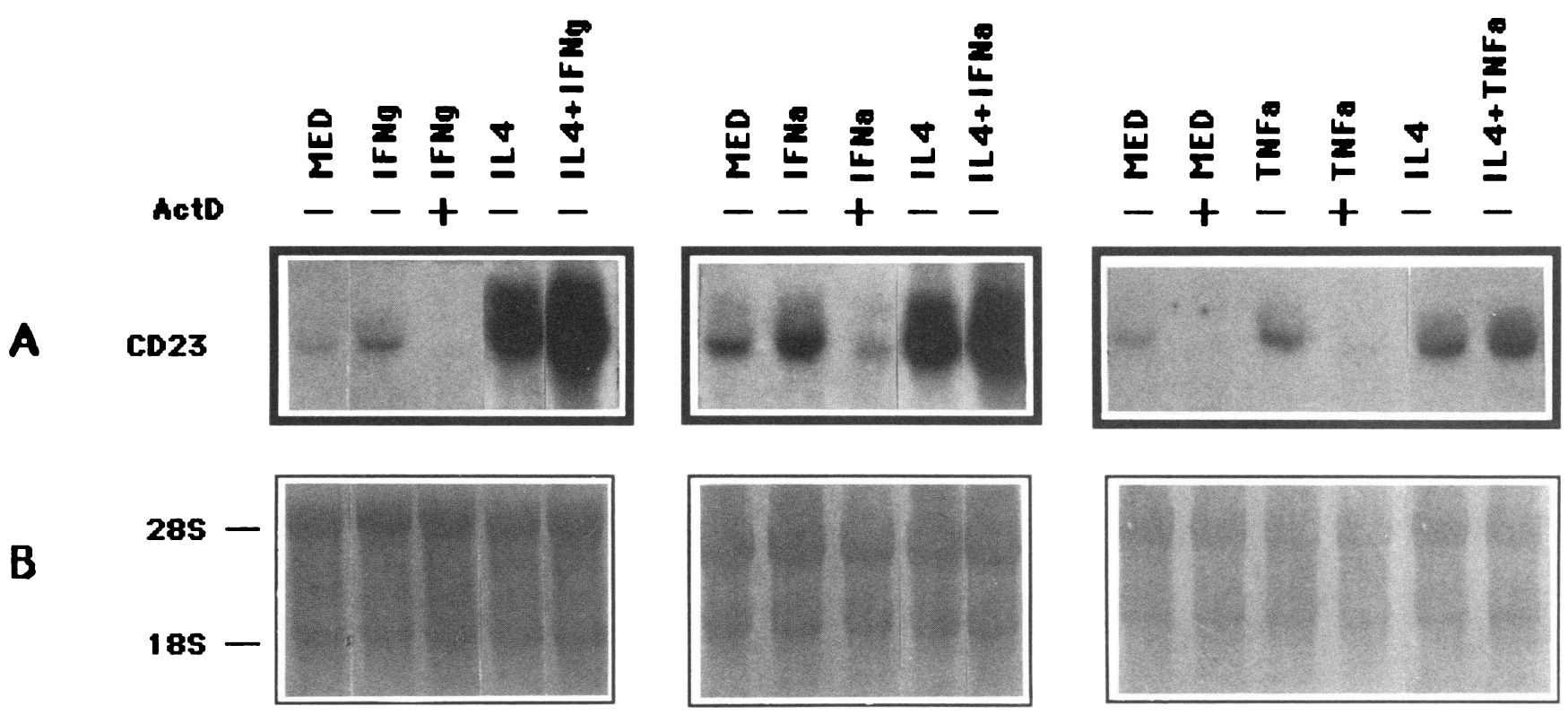

Figure 5. IFNs and TNF $\alpha$ up-regulate steady-state CD23 mRNA. $(A)$ Northern blots of total cellular RNA were hybridized with $\left[{ }^{32} \mathrm{P}\right] \mathrm{PcL}{ }_{2} \mathrm{cDNA}$. (B) Methylene blue staining of the $28 \mathrm{~S}$ and $18 \mathrm{~S}$ RNAs.

than $\mathrm{SCD} 23$ regulates B-CLL proliferation. This view is supported by the lack of BCGF activity of recombinant soluble $\mathrm{CD} 23$ of various sizes (data not shown).

\section{Discussion}

It is well established that virtually all freshly isolated sIgM/ sIgD-bearing B lymphocytes express CD23 (1). Two isoforms of CD23 mRNA (type A and B) have been reported differing by alternate splicing of the same CD23 gene (4). After $24-48 \mathrm{hr}$ of incubation at $37^{\circ} \mathrm{C}$ in the absence of stimulant, normal B cells lose both CD23 mRNA and CD23 antigen whereas SCD23/ IgE-BF accumulates in the culture supernatant $(38,39)$. IL-4 strongly induces the expression of surface CD23 (predominantly type $B$ ) on normal $B$ cells and this is accompanied by an augmentation of the release of sCD23/IgE-BF $(4,38,39)$. These effects of IL-4 on B cells are inhibited by IFN $\gamma$ and IFN $\alpha$ that were shown to act both at the protein and mRNA levels $(13,14,40)$. Typically, in chronic lymphocytic leukemia, the malignant B cells coexpress sIgM, sIgD, CD5, and CD23 (30, 41). The present study indicates that the regulation of CD23 expression on B-CLLs is profoundly abnormal inasmuch as it is significantly increased by IFN $\gamma$ and IFN $\alpha$ as well as by TNF $\alpha$ in the presence or absence of IL-4. The up-regulation of membrane CD23 expression mainly reflects a transcriptional event as the CD23 mRNA increase is blocked by exposure to actinomycin D. Because the density of CD23 on the cell surface depends upon the rate of its cleavage into soluble fragments (sCD23/IgE-BF), it was interesting to show that IFN $\gamma$, IFN $\alpha$, and TNF $\alpha$ increase both the expression of surface CD23 and the release of $\mathrm{SCD} 23 / \mathrm{IgE}-\mathrm{BF}$. Indeed, agents capable of interfering with the cleavage rate of CD23 may induce an apparent upor down-regulation of the surface molecule without affecting its synthesis. For example, this mechanism was shown to account for the increased expression of CD23 on B cells incubated in the presence of IgE or of some anti-CD23 MAb (42, 43). Although the data are not shown, it is important to note that we failed to detect any effect of TNF $\alpha$ on CD23 expression by normal $B$ cells tested under various experimental conditions. The CD23-enhancing activity of IL-2 is in keeping with a recent study (5), its effect is highly variable from one B-CLL clone to the other and can be observed at the mRNA level (not shown). Of note, IL-5 was reported to up-regulate CD23 on normal B cells stimulated by suboptimal concentrations of IL4 (44), whereas in the present report it has no effect when used together with optimal IL-4 concentration.

The present study also indicates that the overexpression of CD23 observed on fresh B-CLLs may be reconstituted in vitro after incubation with IL-4 and the cell-free supernatant of PHA-activated T CLLs (T-PHA SUP). Moreover, the enhancing activity of several such supernatants may be accounted for by their content in IFN $\gamma, \mathrm{TNF} \alpha$, and IL-2. Indeed, the activity was completely suppressed by a cocktail of neutralizing MAbs to the three lymphokines, and conversely it was perfectly mimicked by a mixture of these recombinant lymphokines used exactly at the same concentration as in each $T$ cell supernatant. It is of note that in the murine system, the culture supernatants of both $\mathrm{TH} 1$ and $\mathrm{TH} 2 \mathrm{~T}$ cell clones were shown to superinduce CD23 expression by IL-4-stimulated normal B cells (45). However, in this case, the superinducing activity could not be related to any known cytokine.

The ability to reconstitute in vitro the high level of CD23 observed on fresh B-CLLs by a combination of IL-2, IL-4, IFN $\gamma$, and TNF $\alpha$ does not prove that this mechanism is involved in vivo. However, this possibility is supported by three series of observations. First, TNF $\alpha$ mRNA is constitutively expressed in B-CLLs and the patients display increased serum levels of TNF $\alpha(35,46)$. Second, CLL patients have an enlarged pool of activated $\mathrm{CD}^{+} \mathrm{T}$ cells and natural killer cells, known to be IFN $\gamma$ producers $(36,37)$. Third, our present data show that IL-4 mRNA can be detected by the qualitative PCR technique in fresh $\mathrm{T}$ cells from either normal or leukemic donors; the latter are in turn composed of a very low ratio of 

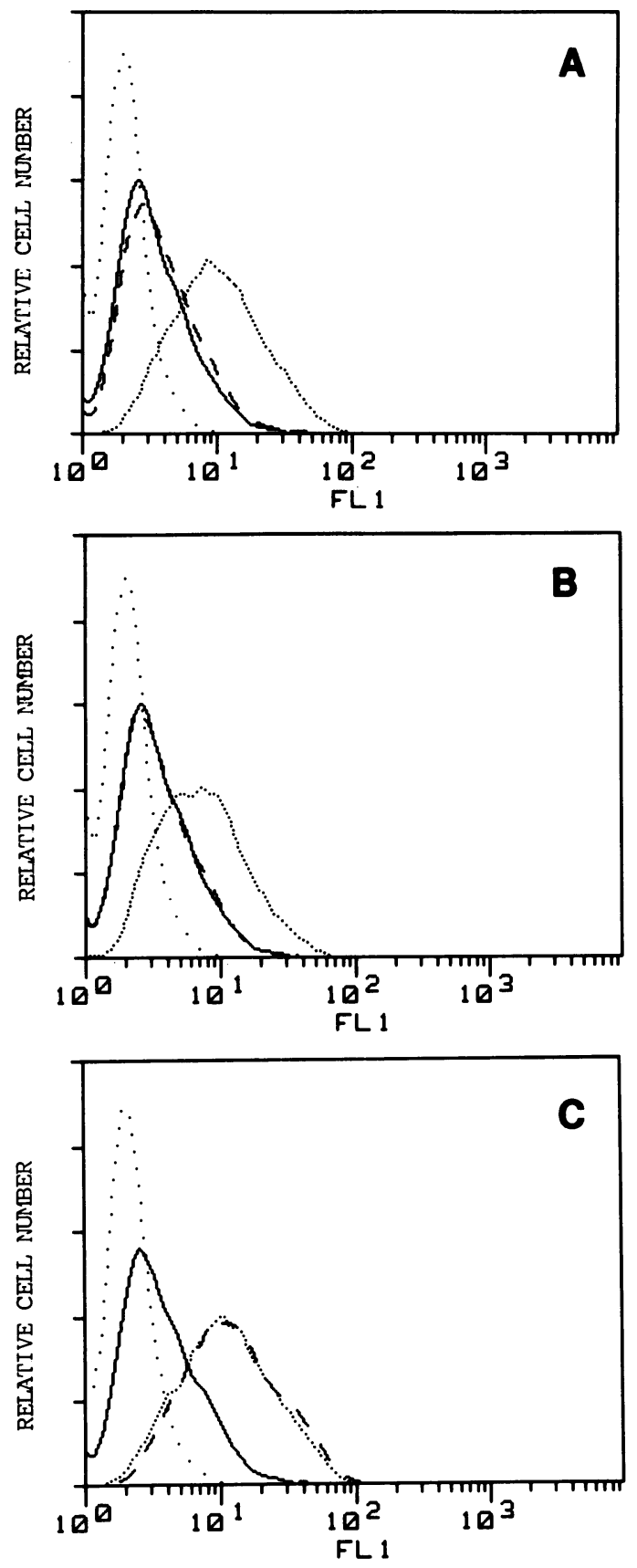

Figure 6. The CD23-superinducing activity of T-PHA SUPs is accounted for by their content in IL-2, IFN $\gamma$, and TNF $\alpha$. CD23 expression on B-CLLs cultured for $2 \mathrm{~d}$ with IL-4 $(10 \mathrm{ng} / \mathrm{ml})(-)$; control MAb is shown as (. . .). (A) B-CLLs cultured with IL-4 and a mixture of IL-2 $(2 \mathrm{U} / \mathrm{ml}), \mathrm{TNF} \alpha(5 \mathrm{ng} / \mathrm{ml})$, and IFN $\gamma(150 \mathrm{U} / \mathrm{ml})$ in the presence (-- ) or the absence (‥) of a cocktail of neutralizing Abs against IL-2 $(10 \mu \mathrm{g} / \mathrm{ml}), \mathrm{TNF} \alpha(10 \mu \mathrm{g} / \mathrm{ml})$, and IFN $\gamma(200 \mathrm{U} /$ $\mathrm{ml})$. (B) B-CLLs cultured with IL-4 and T-PHA SUP in the presence $(--)$ or the absence $(\cdots)$ of the same concentrations of the above cocktail of Abs. (C) B-CLLs cultured with IL-4 and T-PHA SUP $(---)$ or IL-4 and a cocktail of recombinant IL-2, TNF $\alpha$, and IFN $\gamma$ (…) used at the exactly same concentrations as in the T-PHA SUP. $(B$ and $C$ ) One representative experiment out of three.

$\mathrm{CD}^{+} / \mathrm{CD}^{+}$cells. The IL-4 gene is silent in B-CLL cells excluding an autocrine production of IL-4 in this disease. The failure to detect IL-4 mRNA in fresh T cells using a quantita-

\section{$\begin{array}{lllllllllllllll}1 & 2 & 3 & 4 & 5 & 6 & 7 & 8 & 9 & 10 & 11 & 12 & 13 & 14\end{array}$}

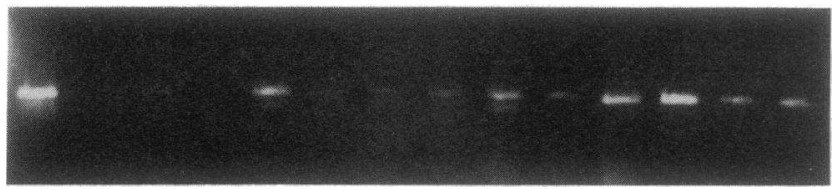

Figure 7. PCR analysis of IL4 mRNA in fresh T cells. Lane 1 , Chinese hamster ovary cells transfected with IL-4 cDNA; lane 2, freshly isolated highly purified tonsillar B lymphocytes; lanes 3-6, fresh T cells from four normal donors; lanes 7-14, fresh T cells from eight CLL patients. $\beta$-Actin mRNA was detectable in each sample (not shown).

tive method (Northern blot) prohibits a comparison between the amount of IL-4 produced by normal and CLL T cells. However, it indicates that the level of IL-4 message is exceedingly low in fresh T-CLLs, and that this should not be taken as evidence to exclude a role for IL-4 in the CD23 overexpression. Similarly, low amounts of IL-6 message, exclusively detected by PCR technique followed by Southern hybridization, are sufficient for allowing autocrine growth of U266 myeloma cell line (47). The notion that IL-4 production in vivo may contribute to the enhanced CD23 expression is further supported by the observations that IL- 4 induces expression of CD8 on CD4 ${ }^{+}$ $T$ cells $(48)$ and that CLL PBMC contain an increased number of $\mathrm{CD}^{+} \mathrm{CD}^{+}$double-positive $\mathrm{T}$ cells (49). We therefore suggest that the overexpression of CD23 on B-CLLs results from an in vivo production of IL-4 combined with an abnormal regulation of the CD23 gene by IFNs and TNF $\alpha$.

The significance of $\mathrm{CD} 23$ overexpression and the precise function of CD23 or of its soluble fragments (sCD23) in CLL disease remain to be elucidated. Nevertheless, our present data clearly indicate that signaling through CD23 molecule on the surface of B-CLLs negatively influence the growth of the leukemic B cells. Divalent $\left(\mathrm{Fab}^{\prime}\right)_{2}$ anti-CD23 MAb, but not their Fab fragments strongly suppress the cytokine-induced B-CLL DNA synthesis indicating that cross-linking of CD23 is required to deliver a negative growth signal. This view is further supported by the ability of Fab fragments to suppress B-CLL proliferation when used in tandem with goat anti-mouse Fab. Soluble CD23, purified from supernatants of EBV-transformed B cell lines (20) as well as the intact $45-\mathrm{kD}$ (membrane) form of CD23 were reported to be mitogenic for normal and transformed B lymphoblasts (50). However, various forms of recombinant soluble CD23 completely lack BCGF activity on B-CLLs in the presence or absence of IL-1 (M. Sarfati, personal observations). In addition, the lack of suppressive activity of anti-CD23 Fab fragments on B-CLL DNA synthesis argues against a potential proliferative effect of endogenously produced soluble $\mathrm{CD} 23$. It also suggests that ligation of $\mathrm{CD} 23$ does not prevent the binding to B-CLLs of a B-cell-derived growth factor. The present findings corroborate with our recent studies showing that cross-linking of $\mathrm{CD} 23$ by anti-CD23 MAb or by its natural ligand (IgE) inhibits normal B cell proliferation in response to IL-4 and that rsCD23 has no BCGF activity (21). Similarly, cross-linking of CD23 suppresses IgE synthesis by U266 myeloma cell line (51). Although the mechanisms underlying the anti-CD23 MAb-induced suppression on B-CLL proliferation is not understood, two possibilities may be considered. First, signaling through different epitopes of the same 


\begin{tabular}{|c|c|c|c|c|}
\hline \multirow[b]{2}{*}{ Added to cultures } & \multicolumn{4}{|c|}{$\left[{ }^{3} \mathrm{H}\right]$ Thymidine incorporation } \\
\hline & Day 2 & Day 3 & Day 4 & Day 5 \\
\hline & \multicolumn{4}{|c|}{$\times c p m$} \\
\hline Medium & $197 \pm 37$ & $820 \pm 179$ & $9,039 \pm 1,196$ & $12,793 \pm 1,748$ \\
\hline Cont MAb & $324 \pm 26$ & $326 \pm 179$ & $10,352 \pm 1,050$ & $11,807 \pm 861$ \\
\hline Anti-CD23 MAb & $155 \pm 10$ & $559 \pm 140$ & $1,458 \pm 85$ & $3,558 \pm 132$ \\
\hline $\mathrm{TNF} \alpha(25 \mathrm{ng} / \mathrm{ml})$ & $273 \pm 78(1.4)$ & $1,847 \pm 414(2.2)$ & $25,158 \pm 2,365(2.7)$ & $49,888 \pm 3,355(3.8)$ \\
\hline IL-2 $(20 \mathrm{U} / \mathrm{ml})$ & $423 \pm 93(2.1)$ & $3,650 \pm 315(4.4)$ & $30,547 \pm 2,211(3.3)$ & $42,632 \pm 5,780(3.3)$ \\
\hline $\operatorname{IFN} \alpha(500 \mathrm{U} / \mathrm{ml})$ & $400 \pm 145(2.0)$ & $4,465 \pm 87(5.4)$ & $35,927 \pm 3,155(3.9)$ & $47,204 \pm 834(3.6)$ \\
\hline $\mathrm{TNF} \alpha+$ cont MAb & $235 \pm 48$ & $1,747 \pm 285$ & $22,755 \pm 2,299$ & $46,716 \pm 6,108$ \\
\hline $\mathrm{TNF} \alpha+$ anti-CD23 MAb & $159 \pm 5$ & $544 \pm 143$ & $3,123 \pm 118$ & $13,335 \pm 1,102$ \\
\hline $\mathrm{IL}-2$ + cont $\mathrm{MAb}$ & $333 \pm 0$ & $4,200 \pm 548$ & $25,354 \pm 1,654$ & $33,651 \pm 2,001$ \\
\hline IL-2 + anti-CD23 MAb & $253 \pm 8$ & $1,470 \pm 108$ & $7,026 \pm 233$ & $15,063 \pm 686$ \\
\hline IFN $\alpha+$ cont $\mathrm{MAb}$ & $310 \pm 26$ & $4,267 \pm 345$ & $31,181 \pm 395$ & $33,055 \pm 3,307$ \\
\hline IFN $\alpha+$ anti-CD23 MAb & $224 \pm 35$ & $1,206 \pm 105$ & $5,373 \pm 635$ & $9,965 \pm 1,041$ \\
\hline
\end{tabular}

Highly purified B-CLL cells were cultured in HB101 serum-free medium at $2 \times 10^{6} / \mathrm{ml}$ for $2,3,4$, or $5 \mathrm{~d}$. Cells were pulsed with $0.5 \mu \mathrm{Ci}$ $\left[{ }^{3} \mathrm{H}\right]$ thymidine for the last $16 \mathrm{~h}$ of the culture period. Anti-CD23 and isotype-matched control MAbs (anti-LoL p1) were used at $10 \mu \mathrm{g} / \mathrm{ml}$. Numbers in parentheses represent stimulation index. One representative experiment out of two.

molecule (i.e., CD20 Ag) may lead to opposite effects on normal B cell proliferation (52). Hence, one particular anti-CD23 MAb (MHM6) was shown to enhance proliferation in activated B cells (53). Further studies confirmed an epitope-specifcity for stimulation through CD23 with the majority of antibodies being nonstimulatory (54). Second, cross-linking of CD23 on SAC-activated and IL-4-supported B cell blasts, induces phosphatidylinositol turnover and $\mathrm{Ca}^{++}$increase (55). These early activation events precede and have been related, in other systems involving B cells, to programmed cell death (56). This

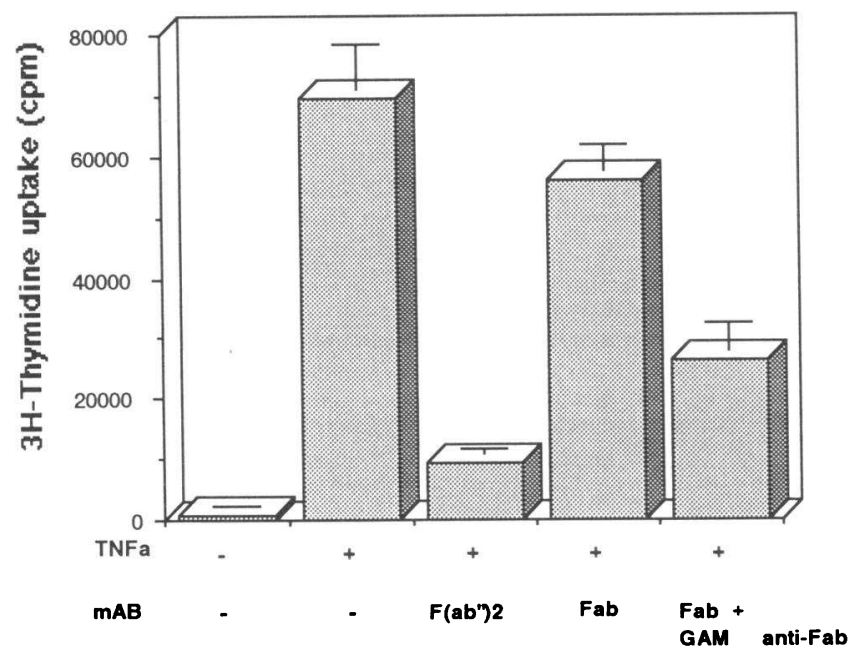

Figure 8. $\mathrm{F}\left(\mathrm{ab}^{\prime}\right)_{2}$ but not $\mathrm{Fab}$ anti-CD23 blocks cytokine-induced DNA synthesis by B-CLLs. B-CLLs $\left(4 \times 10^{5}\right.$ per well $)$ were stimulated for $5 \mathrm{~d}$ with TNF $\alpha(25 \mathrm{ng} / \mathrm{ml})$. Added to cultures: medium, $\mathrm{F}\left(\mathrm{ab}^{\prime}\right)_{2}$ anti-CD23 $(10 \mu \mathrm{g} / \mathrm{ml})$, Fab fragment $(10 \mu \mathrm{g} / \mathrm{ml})$, Fab fragment plus goat anti-mouse IgG (Fab specific) $(10 \mu \mathrm{g} / \mathrm{ml})$. $\left[{ }^{3} \mathrm{H}\right]$ Thymidine was added for the last $16 \mathrm{~h}$ of the culture period. One representative experiment out of three. hypothesis is currently being analyzed. Of note, soluble CD23 and IL-1 may rescue centrocytes in germinal center from death by apoptosis (27). A similar function of endogenously produced soluble CD23 on B-CLLs cannot be ruled out as the malignant B cells can produce IL-1 (57).

Finally, given that fresh B-CLLs, as opposed to normal B cells, express the two CD23 isoforms (type A and B) (30), we postulate that these two CD23 species might have different functions and/or transduce opposite signals to the B-CLL cells. Kikutani and Kishimoto (58), have shown by transfection experiments that only CD23 type B transformed macrophages were capable of IgE-mediated phagocytosis. For B cells, the respective function of the two $\mathrm{CD} 23$ subtypes remains to be elucidated. The differential regulation of CD23 A and B on B-CLLs by various cytokines is currently being evaluated. Despite the requirement for gene knockout studies to help formally establish the contribution of CD23 in B CLL proliferation, this notion is now reinforced by the recent demonstration that the level of CD23 expression in CLL disease has a significant prognostic importance independent of the clinical stage (59).

\section{Acknowledgments}

We wish to thank Norma Del Bosco for excellent secretarial assistance. S. Fournier is a student, G. Delespesse an associate, and M. Sarfati a scholar, all affiliated with the Medical Research Council (Canada). This work was supported by a grant from the Medical Research Council.

\section{References}

1. Kikutani, H., A. Suemura, H. Owaki, H. Nakamura, R. Sato, K. Yamasaki, E. Barsumian, R. Hardy, and T. Kishimoto. 1986. Fce receptor, a specific differentiation marker transiently expressed on mature $B$ cells before isotype switching. J. Exp. Med. 164:1455-1469. 
2. Delespesse, G., M. Sarfati, and H. Hofstetter. 1989. Human IgE-binding factor. Immunol. Today. 10:159-163.

3. Letellier, M., M. Sarfati, and G. Delespesse. 1990. Mechanism of formation of IgE-binding factors (soluble CD23) I. FceRII bearing B cells generates IgEbinding factors of different molecular weights. Mol. Immunol. 26:1105-1112.

4. Yokota, A., H. Kikutani, T. Tanaka, R. Sato, E. Barsumian, M. Suemura, and T. Kishimoto. 1988. Two species of human Fce receptor II (FceRII/CD23): tissue-specific and IL-4-specific regulation of gene expression. Cell. 55:611-618.

5. Hivroz, C., A. Vallé, J. C. Brouet, J. Banchereau, and C. Grillot-Courvalin. 1989. Regulation by interleukin 2 of CD23 expression of leukemic and normal B cells: comparison with interleukin 4. Eur. J. Immunol. 19:1025-1030.

6. DeFrance, T., J. P. Aubry, F. Rousset, B. Vandervliet, J. Y. Bonnefoy, N. Arai, Y. Takebe, T. Yokota, F. Lee, K. Arai, et al. 1987. Human recombinant interleukin 4 induces Fce receptors (CD23) on normal human B lymphocytes. $J$. Exp. Med. 165:1459-1467.

7. Rousset, F., R. DeWaal Malefijt, B. Slierendregt, J. P. Aubry, J. Y. Bonnefoy, T. Defrance, J. Banchereau, and J. E. DeVries. 1988. Regulation of Fc receptor for IgE (CD23) and class II MHC antigen expression on Burkitt's lymphoma cell lines by human IL-4 and IFN $\gamma . J$. Immunol. 140:2625-2632.

8. Prinz, J. C., X. Bauer, G. Mazur, and E. P. Rieber. 1990. Allergen-directed expression of $\mathrm{Fc}$ receptors for $\mathrm{IgE}$ (CD23) on human $\mathrm{T}$ lymphocytes is modulated by interleukin 4 and interferon- $\gamma$. Eur. J. Immunol. 20:1259-1264.

9. Bieber, T., A. Rieger, C. Neuchrist, J. C. Prunz, E. P. Rieber, G. Boltz-Nituleseu, O. Schneider, D. Kraft, J. Ring, and G. Stingl. 1989. Induction of FceR2/ CD23 on human epidermal Langerhan's cells by recombinant interleukin 4 and $\gamma$-interferon. J. Exp. Med. 170:309-314.

10. Capron, M., T. Jouault, L. Prin, M. Joseph, J. C. Ameisen, A. E. Butterworth, J. P. Papin, J. P. Kusnierz, and A. Capron. 1986. Functional study of a monoclonal antibody to IgE Fc receptor (FceR2) on eosinophils, platelets and macrophages. J. Exp. Med. 164:72-89.

11. Hosoda, M., S. Makino, T. Kawabe, Y. Maeda, S. Satoh, M. Takami, M. Mayumi, K. I. Arai, H. Saitoh, and J. Yodoi. 1989. Differential regulation of the low affinity Fc receptor for IgE (FceR2/CD23) and the IL-2 receptor (Tac/p55) on eosinophilic leukemia cell line (Eol-1 and Eol-3). J. Immunol. 143:147-152.

12. Kawabe, T., M. Takami, M. Hosoda, Y. Maeda, S. Sato, M. Mayumi, H. Mikawa, K. I. Arai, and J. Yodoi. 1988. Regulation of Fc $\in$ R2/CD23 gene expression by cytokines and specific ligands (IgE and anti-Fc $\in \mathrm{R} 2$ monoclonal antibody). J. Immunol. 141:1376-1382.

13. Delespesse, G., M. Sarfati, and R. Peleman. 1989. Influence of recombinant IL-4, IFN $\alpha$, and IFN $\gamma$ on the production of human IgE binding factor (soluble CD23). J. Immunol. 142:134-138.

14. TeVelde, A. A., F. Rousset, C. Peronne, J. E. DeVries, and C. G. Figdor. 1990. IFN $\alpha$ and IFN $\gamma$ have different regulatory effects on IL-4-induced membrane expression of Fc $\epsilon$ RIIb and release of soluble Fc $\epsilon$ RIIb by human monocytes. J. Immunol. 144:3052-3059.

15. Vercelli, D., H. H. Jabara, B. W. Lee, N. Woodland, R. S. Geha, and D. Y. M. Leung. 1988. Human recombinant interleukin 4 induces FceR2 CD23 on normal human monocytes. J. Exp. Med. 167:1406-1416.

16. Wu, C. Y., M. Sarfati, C. Heusser, S. Fournier, M. Rubio-Trujillo, R. Peleman, and G. Delespesse. 1990. Glucocorticoids increase the synthesis of IgE by interleukin 4-stimulated human lymphocytes. J. Clin. Invest. 87:870-877.

17. Dugas, B., N. Paul-Eugene, J. Cairns, J. Gordon, A. Calenda, J. M. Mencia-Huerta, and P. Braquet. 1990. Leukotriene $B_{4}$ potentiates the expression and release of Fc $\epsilon$ RII/CD23 and proliferation and differentiation of human B lymphocytes induced by IL-4. J. Immunol. 145:3406-3411.

18. Pauleugene N., B. Dugas, S. Picquot, V. Lagente, J. M. Menciahuerta, and P. Braquet. 1990. Influence of interleukin-4 and platelet-activating factor on the Fc-epsilon-RII/Cd23 expression on human monocytes. J. Lipid Med. 2:95-101.

19. Pène, J., F. Rousset, F. Brière, I. Chrètien, J. Y. Bonnefoy, H. Spits, T. Yokota, K. Arai, J. Banchereau, and J. E. De Vries. 1988. IgE production by normal human lymphocytes is induced by interleukin 4 and suppressed by interferon $\gamma$ and $\alpha$ and prostaglandin E2. Proc. Natl. Acad. Sci. USA. 85:6880-6884.

20. Swendeman, S., and D. A. Thorley-Lawson. 1987. The activation antigen BLAST-2, when shed, is an autocrine BCGF, for normal and transformed B cells. EMBO (Eur. Mol. Biol. Organ.) J. 6:1637-1642.

21. Luo, H., H. Hofstetter, J. Banchereau, and G. Delespesse. 1991. Crosslinking of CD23 antigen by its natural ligand (IgE) or by anti-CD23 antibody prevents B lymphocyte proliferation and differentiation. J. Immunol. 146:212229.

22. Armitage, R. J., L. K. Goff, and P. C. L. Beverley. 1989. Expression and functional role of CD23 on T cells. Eur. J. Immunol. 19:31-35.

23. Sarfati, M., and G. Delespesse. 1988. Possible role of FceRII in the regulation of human IgE synthesis. J. Immunol. 41:2195-2199.

24. Chrétien, I., J. Pène, F. Brière, R. D. Malefijt, F. Rousset, and J. E. DeVries. 1990. Regulation of human IgE synthesis. I. Human IgE synthesis in vitro is determined by the reciprocal effects of interleukin 4 and interferon gamma. Eur. J. Immunol. 20:243-251.

25. Mossalayi, M. D., J. C. Lecron, A. H. Dalloul, M. Sarfati, J. M. Bertho, H.
Hofstetter, G. Delespesse, and P. Debré. 1990. Soluble CD23 (FceRII) and interleukin 1 synergistically induce early human thymocyte maturation. J. Exp. Med. 171:959-964.

26. Mossayali, M. D., M. Arock, J. M. Bertho, C. Blanc, A. H. Dalloul, H. Hofstetter, M. Sarfati, G. Delespesse, and P. Debré. 1990. Proliferation of early human myeloid precursors induced by interleukin-1 and recombinant soluble CD23. Blood. 75:1924-1927.

27. Liu, Y. J., J. A. Cairns, M. J. Holder, S. D. Abbot, K. U. Jansen, J. Y. Bonnefoy, J. Gordon, and I. C. M. Maclennan. 1991. Recombinant 25-kDa CD23 and interleukin $1 \alpha$ promote the survival of germinal center B cells: evidence for bifurcation in the development of centrocytes rescued from apoptosis. Eur. J. Immunol. 21:1107-1114.

28. Sarfati, M., D. Bron, L. Lagneaux, C. Fonteyn, H. Frost, and G. Delespesse. 1988. Elevation of IgE-binding factors in serum of patients with B cell-derived chronic lymphocytic leukemia. Blood. 71:94-98.

29. Sarfati, M., S. Fournier, M. Christoffersen, and G. Biron. 1990. Expression of CD23 antigen and its regulation by IL-4 in chronic lymphocytic leukemia. Leuk. Res. 14:47-55.

30. Fournier, S., I. D., Tran, U. Suter, G. Biron, G. Delespesse, and M. Sarfati. 1991. The in vivo expression of type b CD23 mRNA in B chronic lymphocytic leukemic cells is associated with an abnormally low CD23 upregulation by IL4: comparison with their normal cellular counterparts. Leuk. Res. 15:609-618.

31. Sarfati, M., T. Nutman, C. Fonteyn, and G. Delespesse. 1986. Presence of antigenic determinants common to $\mathrm{Fc} I g E$ receptors on human macrophages $\mathrm{T}$ and B lymphocytes and IgE-binding factors. Immunology. 59:569-575.

32. Chirgwin, J. M., A. E. Przybula, R. J. McDonald, and W. J. Ruther. 1979. Isolation of biologically active ribonucleic acids from sources enriched in ribonuclease. Biochemistry. 18:5294-5300.

33. Brenner, C. A., A. W. Tam, P. A. Nelson, E. G. Engleman, N. Suzuki, K. E. Fry, and J. W. Larrick. 1989. Message amplification phenotyping (mapping): a technique to simultaneously measure multiple mRNAs from small numbers of cells. Biotechniques. 7:1096-1103.

34. Monroy, A. F. 1988. Staining immobilized DNA ladder. Focus. 10:1

35. Foa, R., M. Massaia, S. Cardona, A. Gillio Tos, A. Bianchi, C. Attisano, A. Guarini, P. Francia di Celle, and M. T. Fierro. 1990. Production of tumor necrosis factor-alpha by B-cell chronic lymphocytic leukemia cells: a possible regulatory role of TNF in the progression of the disease. Blood. 76:393-400.

36. Semenzato, G., A. Pezzuto, R. Foà, F. Lauria, and R. Raimondi. 1983. T lymphocytes in B-cell chronic lymphocytic leukemia characterization by monoclonal antibodies and correlation with Fc receptors. Clin. Immunol. Immunopathol. 26:155-161.

37. Totterman, T. H., M. Carlsson, B. Simonsson, M. Bengtsson, and K. Nilsson. 1989. T-cell activation and subset patterns are altered in B-CLL and correlate with the stage of the disease. Blood. 74:786-792.

38. Delespesse, G., H. Hofstetter, M. Sarfati, U. Suter, T. Nakajima, H. Frost, M. Letellier, R. Peleman, and E. Kilchherr. 1989. Human FceRII: molecular, biological and clinical aspects. Chem. Immunol. 47:79-105.

39. Nakajima, T., M. Sarfati, and G. Delespesse. 1987. Relationship between human IgE-binding factors (IgE-BF) and lymphocyte receptors for IgE. J. Immunol. 139:848-854.

40. Denoroy, M. C., J. Yodoi, and J. Banchereau. 1990. Interleukin 4 and interferons $\alpha$ and $\gamma$ regulate Fc $\epsilon 2 / \mathrm{CD} 23$ mRNA expression on normal human B cells. Mol. Immunol. 27:129-134.

41. Digel, W., W. Schoniger, M. Stefanic, H. Janssen, C. Buck, M. Schmid, A. Raghavachar, and F. Porzsolt. 1990. Receptors for tumor necrosis factor on neoplastic B cells from chronic lymphocytic leukemia are expressed in vitro but not in vivo. Blood. 76:1607-1613.

42. Delespesse, G., M. Sarfati, M. Rubio-Trujillo, and T. Wolowiec. 1986. IgE receptors on human lymphocytes. III. Expression of IgE receptors on mitogenstimulated human mononuclear cells. Eur. J. Immunol. 16:1043-1047.

43. Bonnefoy, J. Y., J. Shields, and J. J. Mermod. 1990. Inhibition of human interleukin 4-induced IgE synthesis by a subset of anti-CD23/Fc epsilon RII monoclonal antibodies. Eur. J. Immunol. 20:139-144.

44. Pène, J. F. Rousset, F. Brière, I. Chrétien, J. Wideman, J. Y. Bonnefoy, and J. E. De Vries. 1988. Interleukin 5 enhances interleukin 4-induced IgE production by normal human B cells. The role of soluble CD23 antigen. Eur. J. Immunol. 18:929-935.

45. Keegan, A. D., C. M. Snapper, R. VanDusen, W. E. Paul, and D. H. Conrad. 1989. Superinduction of the murine B cell FceRII by T helper cell clones. J. Immunol. 142:3868-3874.

46. Cordingly, F. T., A. V. Hofbrand, H. E. Heslop, M. Turner, A. Bianchi, J. E. Reittie, A. Vyakarnam, A. Meager, and M. K. Brenner. 1988. Tumor necrosis factor as an autocrine tumour growth factor for chronic B-cell malignancies. Lancet. 1:969.

47. Schwab, G., C. B. Siegall, L. A. Aarden, L. M. Neckers, and R. P. Nordan. 1991. Characterization of an interleukin-6-mediated autocrine growth loop in the human multiple myeloma cell line, U266. Blood. 77:587-593.

48. Paliard, X., R. de Waal Malefijt, J. E. DeVries, and H. Spits. 1988. Inter- 
leukin-4 mediates $\mathrm{CD} 8$ induction on human $\mathrm{CD}^{+} \mathrm{T}$-cell clones. Nature (Lond.). 335:642-644.

49. Platsoucas, C. D., M. Galiniski, S. Kempin, L. Reich, B. Clarkson and R. A. Good. 1982. Abnormal T lymphocyte subpopulations in patients with B cell chronic lymphocytic leukemia: an analysis by monoclonal antibody. J. Immunol. 129:2305-2312.

50. Cairns, J. A., and J. Gordon. 1990. Intact, 45-kDa (membrane) form of CD23 is consistently mitogenic for normal and transformed B lymphoblasts. Eur. J. Immunol. 20:539-543.

51. Scherr, E., E. Macy, H. Kimata, M. Gilly, and A. Saxon. 1989. Binding the low affinity Fc $\in R$ on $B$ cells suppresses ongoing human IgE synthesis. J. Immunol. 142:481-489.

52. Clark, E. A., J. A. Ledbetter. 1989. Structure, function and genetics of human B cell associated surface molecules. Adv. Cancer Res. 52:81-149.

53. Gordon, J., M. Rowe, L. Walker, and G. R. Guy. 1986. Ligation of the CD23, p45 (BLAST-2, EBVCS) antigen triggers the cell-cycle progression of activated B lymphocytes. Eur. J. Immunol. 16:1075-1080.

54. Gordon, J., A. J. Webb, G. R. Guy, and L. Walker. 1987. Triggering of B lymphocytes through CD23: epitope mapping and studies using antibody derivatives indicate an allosteric mechanism of signalling. Immunology. 60:517-521.

55. Kolb, J. P., D. Renard, B. Dugas, E. Genot, E. Petit-Koskas, M. Sarfati, G. Delespesse, and J. Poggioli. 1990. Monoclonal anti-CD23 antibodies induce a rise in intracellular calcium and polyphosphoenositide hydrolysis in human activated B cells: involvement of a GP protein. J. Immunol. 145:429-437.

56. Sarthou, P., N. Henry-Toulme and P. A. Cazenave. 1989. Membrane IgM cross-linking is not coupled to protein kinase C translocation in WEHI-231 B lymphoma cells. Eur. J. Immunol. 19:1247-1252.

57. Morabito, F., E. F. Prasthofer, N. E. Dunlap, C. E. Grossi, and A. B. Tilden. 1987. Expression of myelomonocytic antigens on chronic lymphocytic leukemia B cells correlates with their ability to produce interleukin 1. Blood. 70:1750-1757.

58. Kikutani, H., and T. Kishimoto. 1990. Molecular genetics and biology of two different species of FceRII. Res. Immunol. 141:249-258.

59. Geisler, C. H., J. K. Larsen, N. E. Hansen, M. M. Hansen, B. E. Christensen, B. Lund, H. Nielsen, T. Plesner, K. Thorling, E. Andersen, and P. K. Andersen. 1991. Prognostic importance of flow cytometric immunophenotyping of 540 consecutive patients with B-cell chronic lymphocytic leukemia. Blood. 78:17951802. 